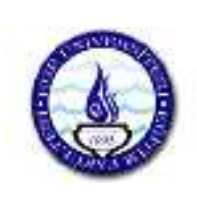

\title{
Lisansüstü Öğrencilerinin Eş Seçimini Etkileyen ve Sınırlandıran Görüş ve nançları
}

\section{Gökçe Sancak Aydın ${ }^{1}$ Ayhan Demir ${ }^{2}$}

\section{$\ddot{O} \mathbf{z}$}

$\mathrm{Bu}$ çalışmada lisansüstü öğrencilerinin eş seçimini etkileyen ve sınırlandıran görüş ve inançlarını araştırmak amaçlanmıştır. Bu amaca yönelik olarak, araştırmacılar tarafından geliştirilmiş görüşme formu kullanılarak eş seçiminde etkili olan görüş ve inançlar belirlenmiştir. Ayrıca, katılımcılarla yapılan görüşmelerde Larson tarafından belirtilen eş seçiminde 9 sınırlayıcı inancın lisansüstü öğrencilerinde ne ölçüde yaygın olduğu da incelenmiştir. Veriler 24 lisansüstü öğrencisi ile görüşülerek ve görüşmelerin içerik analizi yapılarak elde edilmiştir. Çalışmada eş seçimini etkileyen özellikler ve sınırlandıran olumsuz inançlar araştırılırken tümevarım, Larson tarafından bildirilen eş seçiminde 9 sınırlayıcı inanç araştırılırken ise tümdengelim yöntemi kullanılmıştır. Sonuçlar eş seçiminde özellikler bakımından kişisel özellikler, değerler, çevrenin etkisi, çiftler arasındaki uyum, fiziksel çekicilik ve maddiyat gibi özelliklerin ön planda olduğunu göstermiştir. Eş seçiminde etkili olan katılımcıların olumsuz algıladıkları inançlar bakımından ise romantik inançların, evliliğe dair olumsuz inançların, toplumsal ve kültürel inançların, mükemmeliyetçiliğin, olumsuz örnekleri genellemenin etkili olduğunu belirlenmiştir. Sınırlayıcı inançlar olarak ise katılımcıların birlikte yaşamanın evlilikte mutluluğu artıracă̆ tesadüfün önemli olduğu ve mükemmel eş bulana kadar evlenmemeliyim inançlarına genel olarak katıldıkları görülmüştür.

Anahtar Kelimeler: Eş seçimini etkileyen özellikler, eş seçiminde sınırlayıcı inançlar, lisansüstü öğrencileri

1 Yrd. Doç. Dr., Bozok Üniversitesi Eğitim Fakültesi, Eğitim Bilimleri Bölümü, gsancak.aydin@bozok.edu.tr

${ }^{2}$ Prof. Dr., Orta Doğu Teknik Üniversitesi, Eğitim Bilimleri Bölümü, aydemir@metu.edu.tr 


\title{
Opinions and Beliefs Affecting and Limiting the Mate Selection of Graduate Students
}

$$
\text { Submitted by 2017-06-19 }
$$$$
\text { Accepted by 2017-10-25 }
$$

\begin{abstract}
The aim of this study is to understand the characteristics and constraining beliefs that are effective in choosing the mate of graduate students. In the research, the characteristics and negative beliefs that are effective in the selection of mates and the prevalence of the 9 constraining beliefs specified by Larson were examined in graduate students by using the interview form developed by the researchers. For this purpose, 24 graduate students were interviewed and the interviews were analyzed by content analysis method. In the study, the deductive method was used to investigate the characteristics and negative beliefs affecting mate selection and the inductive method was used to investigate 9 constraining beliefs in mate selection reported by Larson. The results of the research showed that the characteristics of the mates were features such as personal characteristics, values, environment effect, harmony between couples, physical attractiveness, and materiality. In terms of the negative beliefs that are effective in the choice of the mate, romantic beliefs, negative beliefs about marriage, societal and cultural beliefs, perfectionism, generalizing the negative examples are mentioned as important in mate selection. As constraining beliefs, cohabitating will enhance happiness in future marriage, chance and coincidence are important in mate selection, and I should not marry until I find the perfect partner beliefs are generally mentioned by participants.
\end{abstract}

Keywords: Characteristics affecting mate selection, constraining beliefs in mate selection, graduate students 


\section{Giriş}

Eş seçimi insanlık tarihi boyunca insanoğlunu en çok etkileyen seçimlerden biri olmuştur. Hızla değişen çağımızda eş seçiminde bireylerin birbirinden farklı özelliklere önem verdiği ve birtakım olumlu ya da olumsuz düşünceler ile eş seçim sürecine girdiği gözlenmektedir. Eş seçimini etkileyen özelliklerin neler olduğu çeşitli kuramlarca ele alınmıştır. Eş seçiminin biyolojik yanına vurgu yapan evrim kuramı, eş seçiminin sosyal yanını vurgulayan sosyal değiş tokuş kuramı, eş seçiminde kültürel rollerin önemini vurgulayan sosyal rol kuramı, benzerliğin önemini vurgulayan benzerlik ve eş seçiminde farklılığın rolünü vurgulayan farklılık kuramları bunlardan bazılarıdır.

Evrim kuramı Darwin' in (2008) türlerin evrimi kuramını temel almaktadır. Bu kurama göre çevredeki değişimlere uyum sağlama konusunda başarılı olan türler doğal olarak seçilmekte ve ayakta kalmaktadır. Darwin, eşeysel seçilim (sexual selection) kavramından söz ederek organizmaya üreme, hayatta kalma avantajı sağlayan özelliklere dikkat çekmektedir. Evrim kuramı eş seçiminde bir cinsiyet ayrımından bahsetmekte ve türün devamı için erkeklerin daha çok doğurganlığın ipuçlarını taşıyan (gögüis kalça oranı, sağlıklı cilt vb.) fiziksel çekiciliğe önem verdiğini (Buss, 1994), kadınların ise daha çok iyi kaynaklara ve maddi refaha önem verdiğini bildirmektedir (Buss, 1989, 1994). Bu özelliklerin yanı sıra evrim kuramına göre yaratıcılık, müzik, dil, sanat, mizah ve diğer insanlara yarar sağlamaya çalışmak iyi genlere sahip olmanın işaretleridir. Bireyler eş seçimlerinde bu işaretleri dikkate almaktadırlar (Miller, 2000). Buss ve diğerleri (1990), eş seçiminde etkili olan belirgin özellikleri incelemişler ve zeka, iyilik, anlayışlı olma, sağlık, benzer dini inançlar, benzer politik görüş ve aşkın evrensel olarak bir çok kültürde aranan özellikler olduğuna dikkat çekmişlerdir.

Sosyal değiş tokuş kuramına göre ise eş seçim sürecinin ardında bireyler arasındaki kaynakların değiş tokuş edilmesi yatmaktadır (Sprecher, 1998). Bir ilişkide eşi çekici kılan yanlar (örneğin, cinsellik, sosyal statü, duygusal güvenlik) kişi tarafında ödül olarak algılanan özelliklerdir (Levinger, 1976). Buna karşılık ilişkide hoşa gitmeyen yanlar (aday eşin madde kullanması, işi olmaması gibi) ise bedel olarak tanımlanır (Kalkan, 2012). Bunların yanında tercih edilebilecek seçeneklerin varlığı da ilişkiyi etkilemektedir. Sosyal değisş tokuş kuramına göre eş seçiminde etkili olan ilke en yüksek ödül ve en düşük bedeli sağlayarak kazançlı olan ilişkiyi sürdürmektir (Knox ve Schacht, 2008; Sprecher, 1998). 
Sosyal rol kuramı eş seçiminde cinsiyetler arasındaki farklılıkları vurgulamaktadır (Eagly ve Wood, 1999). Bu kuram, kadın ve erkeklerin eş seçimlerindeki farklılıklarını toplumun kadın ve erkeğe biçtiği roller ile açıklamaktadır. Sosyal rol kuramına göre, her iki cinsiyette birbirinden farklı sorumluluklar içeren iş, aile ve evlilik rollerine göre eş tercihlerini gerçekleştirmektedir (Kalkan, 2012). Örneğin, toplumsal olarak kadından yakın, bakım sağlayan ve ilgili olması beklenirken ve bu özellikler bir kadını eş adayı olarak çekici kılarken, erkek için iyi kazanç sahibi olmak, güç sahibi olmak, girişken olmak gibi özellikler beklenmektedir.

Benzerlik kuramı (homogamy theory), sosyal sınıf, ırk, cinsiyet, din ve statü gibi özellikler açısından kişilerin kendisine benzer kişilerden etkilendiğini iddia etmektedir (Knox ve Schacht, 2008). Eş seçiminde benzerlik aranan en önemli değişkenler ise fiziksel görünüm, yaş, ırk, din, sosyal sınıf, kişilik ve değerler olarak sıralanmaktadır (Benokraitis, 2014). Benzerlik kuramının aksine, farklılık kuramlarından tamamlayıcı ihtiyaçlar kuramı (complementary needs teory), bireylerin kendi ihtiyaçlarını tamamlayıcı olan yani kişinin kendinden farklı özellikler gösteren kişileri seçme eğiliminde olduğunu savunmaktadır (Knox ve Schacht, 2008; Schellenberg ve Bee, 1960).

Belirtildiği gibi pek çok kuram kişinin eş seçiminde etkili olan özellikleri incelemiş ve eş seçimi davranışında etkili olan özellikleri anlamaya çalışmıştır. Eş seçiminde kişinin olası eşte $\operatorname{aradığı~özelliklerin~yanı~sıra~kişinin~sahip~olduğu~düşüncelerin~de~etkili~olduğu~}$ bilinmektedir. lişki kurarken bireyler, ilişkilerin nasıl olması, ilişkilerin ne gibi kurallar ile yönlendirilmesi gerektiği gibi birtakım önceden sahip oldukları düşüncelerle ilişkiye başlamaktadır (Sprecher ve Metts, 1999). Pek çok araştırma eş seçiminde sadece eş adayının özelliklerinin değil, bununla birlikte bireyin evliliğe dair inançlarının da eş seçiminde etkili olduğunu belirtmektedir (Baucom ve Epstein, 1990; Larson, 1992; Sharp ve Ganong, 2000). Evliliğe doğru ilerlerken kişiler, evlilik ile ilgili gerçekdışı inançlara sahip olmaya eğilimli olabilmektedir (Wright, 1992). Evlilikte ise gerçekçi olmayan bu olumsuz inançların evlilik niteliği ile olumsuz biçimde ilişkili olduğu bildirilmektedir (Larson ve Holman, 1994). Eş seçiminde bu gerçekçi olmayan düşünceleri Larson (1992) şu şekilde sıralamıştır; "tek ve yalnızca bir doğru kişi vardır inancı” dünyada evlenilebilecek sadece bir doğru kişi olduğundan bahsetmektedir. "Mükemmel eş inancı" mükemmel bir eş bulmadan evlenmenin mümkün olmayacağına işaret etmektedir. "Mükemmel olmam gerekli (mükemmel ben) inancı" kişinin evlenmek için önce kendisinin mükemmel ve eksiksiz bir hale gelmesi düşüncesini içermektedir. "Mükemmel ilişki inancı" evlenmeden bir ilişkinin tam ve eksiksiz 
olduğunun ispat edilmesi gerektiğine dair inançtır. "Çaba sarf etmeliyim inancı" kişinin çaba sarf ettiğinde evlenmek üzere seçtiği kişiyle mutlu olabileceğine dair inançtır. "Aşs yeterlidir inancı" evlenmek için aşık olmanın yeterli bir neden olduğuna dikkat çekmektedir. "Birlikte yaşamak gerekli inancı" evlenmeden önce birlikte yaşamanın mutlu bir evlilik sahibi olmayı garanti edeceğine dair inançtır. "Zıt kutuplar bir birini çeker inancı" evlilikte bir birinden tamamen farklı özelliklere sahip olmanın eş seçiminde gerekli olduğuna dair inançtır. Son olarak "Seçim yapmak kolaydır inancı" ise eş seçiminde şans ve tesadüf faktörlerinin etkili olduğu düşüncesini içermektedir.

$\mathrm{Bu}$ çalışmanın amacı lisansüstü öğrencilerinin eş seçimlerini etkileyen ve sınırlandıran görüş ve inançlarını anlamaktır. Eş seçiminde etkili olan sınırlayıcı inançların eş seçimi sürecine olumsuz etkisi göz önünde bulundurulduğunda (Cobb, Larson ve Watson, 2003; Larson, 1992), bu süreçte etkin olan görüş ve sınırlayıcı inançların araştırılması büyük önem taşımaktadır. Ülkemizde eş seçimini etkileyen özelliklere yönelik bazı çalışmalara yapılmış olsa da (örn. Bacanlı, 2001; Yıldırım, 2007) sınırlı sayıda çalışma tarafından eş seçiminde etkili olan inançlar araştırılmıştır. Uluslararası alanyazında ise birçok çalışmanın eş seçimine ve evliliğe dair gerçekçi olmayan inanç ve beklentilere odaklandığı görülmektedir (Johnson, 2009; Sharp ve Ganong, 2000). Ülkemizde ise nitel araştırma yöntemi kullanılarak eş seçiminde etkili olan özellikleri ve sınırlayıcı inançları bir arada inceleyen bir çalışmaya henüz rastlanmamıştır. Tüm bunlar göz önünde bulundurulduğunda bu çalışmadan elde edilecek bilgilerin lisansüstü öğrencilerinin eş seçimi üzerine sağlıklı değerlendirmeler yapmalarına yardımcı olmak için bireylere ve onlara destek sunan üniversite danışma merkezleri ve aile danışma merkezlerine katkı sunacağı düşünülmektedir.

\section{Yöntem}

Çalışmada lisansüstü öğrencilerinin eş seçimlerini etkileyen ve sınırlandıran görüş ve inançları anlamak amacıyla bir nitel araştırma deseni olan olgubilim deseni kullanılmış ve bu amaçla, katılımcılarla derinlemesine görüşmeler yapılmıştır.

\section{Çalışma Grubu}

$\mathrm{Bu}$ çalışmanın örneklemini bir devlet üniversitesinde öğrenim görmekte olan nişanlı ya da evli olmayan heteroseksüel 24 lisansüstü öğrencisi oluşturmaktadır. Türkiye statistik Kurumuna göre (2016) Türkiye'de evlenme yaşı kadınlar için 23.9 erkekler için 27'dir. Bu yaşlar lisansüstü dönemine denk geldiği için ve bu örneklem araştırmacılar tarafından ulaşılabilir olduğu için çalışmanın örneklemi bu gruptan seçilmiştir. Öğrencilerin 14’ü kadın 
(\% 58.3), 10’u erkek (\% 41.7) öğrencilerden oluşmaktadır. Çalışmaya katılan lisansüstü öğrencilerinin 8'i Eğitim Fakültesi (\% 33.3), 8'i Fen Edebiyat Fakültesi (\% 33.3), 4'ü Mühendislik Fakültesi (\% 16.7), 4’ü ktisadi ve dari Bilimler Fakültesi (\% 16.7) öğrencisidir. Katılımcıların 15'i yüksek lisans, 9'u doktora öğrencisidir. Çalışmanın katılımcılarının yaşları 23 ile 32 arasında değişmektedir ve katılımcıların yaş ortalaması 26.58' dir ( $S s=2.98)$.

\section{Veri Toplama Süreci}

Olgubilim çalışmalarında ayrıntılı ve derin görüşmeler yapılması sağlıklı veri toplama için önerilmektedir (Creswell, 2007). Bu nedenle bu çalışmanın verileri örneklemdeki katılımcılarla yapılan görüşmelerle toplanmıştır. Görüşmelerde kullanılan görüşme formunun geliştirilmesi için ilk olarak konuyla ilgili alanyazın taraması yapılarak eş seçimiyle ilgili olan maddeler belirlenmiş ve bu maddeleri içeren taslak bir görüşme formu hazırlanmıştır. Taslak form soruların içeriği ve ifadelerin anlaşılır olmasıyla ilgili geribildirim almak amacıyla psikolojik danışma ve rehberlik alanında görev yapan üç uzmanın görüşüne sunulmuştur. Gelen geribildirimler dikkate alınarak taslak form tekrar düzenlenmiştir. $\mathrm{Bu}$ formla üç lisansüstü öğrencisinin katıldığı bir pilot uygulama gerçekleştirilmiştir. Bu uygulamadan sonra geribildirimler doğrultusunda tekrar düzenlemeler yapılarak görüşme formuna son şekli verilmiştir. Görüşme formu kişisel bilgiler (yaş, bölüm, ilişki durumu vb.) ile ilgili sorular ve eş seçimini etkileyen özellik ve inançlara odaklanan on bir açık uçlu soruyu içermektedir.

\section{şlem Yolu}

Lisansüstü öğrencilerinin eş seçimini etkileyen görüş ve inançlarını belirlemek amacıyla hazırlanan görüşme formu ve uygulamada dikkat edilecek konuları içeren araştırma önerisiyle ilgili üniversitenin etik kuruluna başvurulmuş ve gerekli uygulama izini alınmıştır. zin sonrasında çeşitli fakültelerden lisansüstü öğrencilerine tek tek ulaşılmış gönüllü olarak araştırmaya katılmayı kabul edenlerle görüşme zamanları belirlenerek görüşme planı çıkarılmıştır. Katılımcıların ses kaydı için verdikleri izin sonrasında görüşmeler kaydedilerek gerçekleştirilmiştir. Bu kayıtlar deşifre edilerek yazılı bir metine dönüştürülmüştür.

\section{Verilerin Analizi}

Çalışmadan elde edilen verileri analiz etmek amacıyla, içerik analizi yöntemi kullanılmıştır. Görüşmelerden elde edilen yazılı metinler, çalışmanın güvenilirliğini artırmak amacıyla iki farklı kodlayıcı tarafından kodlanmıştır. Kodlama işlemi gerçekleştirildikten sonra, araştırmacılar tarafından kodlar bir araya getirilmiş ve kodlar arasındaki ortak yanlar bulunarak tematik kodlama işlemi gerçekleştirilmiş, böylece elde edilen veriler kodlar yardımı 
ile kategorize edilmiştir. Tematik kodlama ilk aşamada yapılan kodlamaların düzenlenmesini ve aralarında anlamlı ilişkiler kurulmasını mümkün kılmaktadır (Yıldırım ve Şimşek, 2011). Çalışmada eş seçiminde etkili olan özelliklere ve olumsuz inançlara dair katılımcıların görüşleri ele alınırken tümevarım yöntemi, eş seçiminde sınırlayıcı inançlara dair görüşler alınırken, Larson (1992) tarafından sınırlayıcı olarak tanımlanan 9 tip inanç temel alınarak tümdengelim yöntemi kullanılmıştır.

Maxwell (2009) nitel araştırmalarda geçerliliği artırmak için yoğun uzun süreli görüşmeler yapılmasını, zengin veri sağlanmasını, genel ifadeler yerine gerçek sayılara yer verilmesini önermektedir. Bu çalışmanın geçerliliğini artırmak amacıyla Maxwell (2009) tarafından önerilen bu kriterler dikkate alınmış, zengin veri sağlamak için ayrıntılı ve derin görüşmeler yapılmıştır. Bunun yanında veriler sunulurken bazı, nadiren gibi ifadeler yerine katılımcıların görüşlerinin frekansları verilmiştir. Nitel araştırmalarda iç güvenirliği artırmak amacıyla veriler yorum katılmadan doğrudan alıntılar ile sunulabilmektedir (LeCompte ve Goetz, 1982). Yıldırım ve Şimşek (2011) doğrudan alıntılardan yararlanmanın geçerlik için önemli olduğunu belirtmektedir. Bu çalışmada da iç güvenirliği ve geçerliği artırmak için alıntılardan yararlanılmış, elde edilen bulgular sunulurken katılımcılar için "K" ifadesi ve numaralar kullanılmıştır.

\section{Bulgular}

Çalışmada eş seçimini etkileyen ve sınırlandıran görüş ve inançları keşfetmek amacıyla katılımcılara görüşme soruları sorulmuş ve elde edilen bilgiler 1şı ğında bulgular, eş seçiminde etkili olduğu düşünülen özelliklere dair görüşler, eş seçiminde etkili olduğu düşünülen olumsuz inançlara dair görüşler ve eş seçiminde etkili olan dokuz tip sınırlayıcı inanca dair görüşler biçiminde başlıklanarak sunulmuştur. Her bir başlığın altında kümelenen benzer kodlar bir temayı oluşturmuş ve ilgili başlıkta önce ortaya çıkan temalar, daha sonra ilgili temalarda yer alan kodlar ve son olarak da en çok tekrarlanan kodlar sunulmuştur.

\section{Eş Seçiminde Etkili Olduğu Düşünülen Özelliklere Dair Görüşler}

Çalışmada eş seçimini etkileyen özelliklere bakıldığında kişisel özellikler, de ğerler, çevrenin etkisi, çiftler arasındaki uyum, fiziksel çekicilik ve maddiyat temalarının ortaya çıktığ görülmüştür. Kişisel özellikler teması eş seçiminde kişinin eş adayında aradığı kişiye özgü özellikler olarak ifade edilmiştir. Çalışmada bu tema altında tekrarlanan kodların eğitim, iletişim, kişilik, öğrenmeye-gelişime açıklık, güvenilirlik, saygı, yardımseverlik, empatik 
anlayışa sahip olma, mantıklı olma, mizah sahibi olma, iyi bir zekaya sahip olma, güçlü olma, temiz olma, neşeli olma, sosyallik, sağlık ve takdir etme gibi özellikler olduğu görülmüştür.

Değerler teması ise katılımcıların eş seçiminde etkili olan ideoloji, din gibi değerlerini ifade etmektedir. Bu temanın altında ortaya çıkan kodların ise politik görüş, dini görüş, eşitlik gibi özellikler olduğu görülmüştür. Çevrenin etkisi temasında katılımcıların ailenin onayı, aile uyumu, arkadaşların onayı gibi bireyin yakın çevresinde yer alan kişilerin görüşlerinin eş seçiminde etkisini ifade etmektedir. Bu tema altında katılımcılar aile kodu olarak geçen ailenin onayı, aday eşin kendi aileleri ile uyumu ve eş adayı ile kendi aileleri arasındaki uyumu ve benzer biçimde arkadaş kodu olarak geçen arkadaşları tarafından eş adayının sevilmesi ve onaylanmasının, yine arkadaşlarıyla aday eşin uyumlu olmasının önemine dikkat çekmişlerdir.

Çiftler arasındaki uyum teması ise çift olarak bireylerin ilişkilerindeki uyum olarak ifade edilmektedir. Bu temanın altında katılımcılar aday eş ile uyumlu olma, benzer özelliklere sahip olma (boş zaman etkinlikleri, hobiler, kültür, hayat görüşleri gibi) ve ilişki içerisinde yapıcı olmanın eş seçiminde dikkat edecekleri unsurlar olduğunu belirtmişlerdir. Fiziksel çekicilik teması kişilerin eş seçiminde fiziksel çekiciliğe verdiği önemi ifade ederken, maddiyat teması eş seçiminde kişilerin maddi kaynak sağlayıcı unsurları dikkate almaları olarak ifade edilmiştir. Bu temalarda ise fiziksel çekiciliğin eş seçimlerinde etkili olduğunu çoğunluk erkek katılımcılar ifade ederken, statü, meslek ve kazancın yüksek ya da kendisine denk olmasını ifade eden maddiyat temasının eş seçiminde etkili bir özellik olduğunu genel olarak kadın katılımcılar ifade etmiştir. Katılımcıların eş seçiminde etkili olan özelliklere dair s1k tekrarlayan görüşleri Tablo 1' de sunulmuştur.

Tablo 1. Katılımcıların Eş Seçiminde Etkili Olan Özelliklere Dair Sık Tekrarlanan Görüşleri

\begin{tabular}{lccc}
\hline Etkili Özellikler & Kadın & Erkek & Toplam \\
& f & f & f \\
\hline Uyum & 10 & 8 & 18 \\
\hline Eğitim & 10 & 6 & 16 \\
\hline Benzer özellikler & 9 & 6 & 15 \\
\hline letişim & 9 & 5 & 14 \\
\hline Politik görüş & 7 & 7 & 14 \\
\hline Fiziksel çekicilik & 4 & 10 & 14 \\
\hline Kişilik & 8 & 5 & 13 \\
\hline Aile & 8 & 3 & 11 \\
\hline Öğrenmeye-gelişime açıklık & 7 & 4 & 11 \\
\hline Yapıcı olma & 7 & 4 & 11 \\
\hline Güvenilirlik & 5 & 6 & 11 \\
\hline Dini görüş & 7 & 4 & 11 \\
\hline Saygi & 7 & 4 & 11 \\
\hline
\end{tabular}


Tablo 1 incelendiğinde, katılımcıların eş seçiminde önem verdikleri özellikler bakımından hem kadın hem erkekler için aday eş ile uyum ( $\left.f_{\text {Toplam }}=18 ; f_{\text {Kadın }}=10 ; f_{\text {Erkek }}=8\right)$, eğitim $\left(f_{\text {Toplam }}=16 ; f_{\text {Kadın }}=10 ; f_{\text {Erkek }}=6\right)$, benzer özellikler $\left(f_{\text {Toplam }}=15 ; f_{\text {Kadın }}=9 ; f_{\text {Erkek }}=6\right)$, iletişim $\left(f_{\text {Toplam }}=14 ; f_{\text {Kadın }}=9 ; f_{\text {Erkek }}=5\right)$, politik görüş $\left(f_{\text {Toplam }}=14 ; f_{\text {Kadın }}=7 ; f_{\text {Erkek }}=7\right)$, $\operatorname{kişilik~}\left(f_{\text {Toplam }}=13 ; f_{\text {Kadın }}=8 ; f_{\text {Erkek }}=5\right)$, aile $\left(f_{\text {Toplam }}=11 ; f_{\text {Kadın }}=8 ; f_{\text {Erkek }}=3\right)$, öğrenmeye ve gelişime açıklık $\left(f_{\text {Toplam }}=11 ; f_{\text {Kadın }}=7 ; f_{\text {Erkek }}=4\right)$, yapıcı olma $\left(f_{\text {Toplam }}=11 ; f_{\text {Kadın }}=7 ; f_{\text {Erkek }}=\right.$ $4)$, güvenilirlik $\left(f_{\text {Toplam }}=11 ; f_{\text {Kadın }}=5 ; f_{\text {Erkek }}=6\right)$, dini görüş $\left(f_{\text {Toplam }}=11 ; f_{\text {Kadın }}=7 ; f_{\text {Erkek }}=4\right)$ ve sayg1 $\left(f_{\text {Toplam }}=11 ; f_{\text {Kadın }}=7 ; f_{\text {Erkek }}=4\right)$ gibi özelliklerin ön plana çıktığı görülmektedir. $\mathrm{Bu}$ sık tekrarlanan görüşlerin yanında, eş seçiminde katılımcıların diğer önem verdikleri özellikler yardımseverlik $\left(f_{\text {Toplam }}=6 ; f_{\text {Kadın }}=2 ; f_{\text {Erkek }}=4\right)$, eşitlik $\left(f_{\text {Toplam }}=4 ; f_{\text {Kadın }}=3 ; f_{\text {Erkek }}=\right.$ $1)$, arkadaşlar $\left(f_{\text {Toplam }}=3 ; f_{\text {Kadın }}=1 ; f_{\text {Erkek }}=2\right)$, temiz olma $\left(f_{\text {Toplam }}=3 ; f_{\text {Kadın }}=2 ; f_{\text {Erkek }}=1\right)$, neşeli olma $\left(f_{\text {Toplam }}=3 ; f_{\text {Kadın }}=2 ; f_{\text {Erkek }}=1\right)$, sağlık $\left(f_{\text {Toplam }}=3 ; f_{\text {Kadın }}=1 ; f_{\text {Erkek }}=2\right)$, takdir etme $\left(f_{\text {Toplam }}=1 ; f_{\text {Kadın }}=1 ; f_{\text {Erkek }}=0\right)$ biçiminde sıralanmıştır. Bu özelliklere ek olarak, kadın katılımcılar erkeklere oranla daha sık olarak eş seçiminde statü $\left(f_{\text {Toplam }}=6 ; f_{\text {Kadın }}=6 ; f_{\text {Erkek }}=\right.$ $0)$, meslek $\left(f_{\text {Toplam }}=6 ; f_{\text {Kadın }}=5 ; f_{\text {Erkek }}=1\right)$, empatik anlayışa sahip olma $\left(f_{\text {Toplam }}=5 ; f_{\text {Kadın }}=5\right.$; $\left.f_{\text {Erkek }}=0\right)$, mantıklı olma $\left(f_{\text {Toplam }}=4 ; f_{\text {Kadın }}=4 ; f_{\text {Erkek }}=0\right)$, mizah sahibi olma $\left(f_{\text {Toplam }}=4 ; f_{\text {Kadın }}\right.$ $\left.=4 ; f_{\text {Erkek }}=0\right)$, güçlü olma $\left(f_{\text {Toplam }}=3 ; f_{\text {Kadın }}=3 ; f_{\text {Erkek }}=0\right)$, zeka $\left(f_{\text {Toplam }}=4 ; f_{\text {Kadın }}=4 ; f_{\text {Erkek }}=\right.$ $0)$, maddiyat $\left(f_{\text {Toplam }}=3 ; f_{\text {Kadnn }}=3 ; f_{\text {Erkek }}=0\right)$, sosyallik $\left(f_{\text {Toplam }}=3 ; f_{\text {Kadın }}=3 ; f_{\text {Erkek }}=0\right)$ gibi özelliklerin önemine dikkat çekerken, erkek katılımcıların kadın katılımcılara oranla fiziksel çekiciliği $\left(f_{\text {Toplam }}=14 ; f_{\text {Kadın }}=4 ; f_{\text {Erkek }}=10\right)$ daha fazla önemsedikleri belirlenmiştir.

Aşağıda bazı katılımcıların eş seçiminde etkili olduğunu düşündükleri özelliklere dair alıntılar sunulmuştur. Görüşmelerde ailenin eş seçiminde etkin olabileceği ifade edilmiştir. Katılımcıların eş seçiminde ailenin önemli bir role sahip olduğunu vurgulayan görüşlerine ilişkin birkaç örnek aşă̆ıda sunulmuştur:

"Her ne kadar kişi özgür düşündüğünü savunsa da ailesi tarafından belirlenen kriterlerden etkileniyor." K1 (Kadın)

"Benim ailemin görüşü çok etkilidir. Hatta teyzelerimin bile etkilidir. Yani geniş ailem de etkili bu süreçte. Aslında kendi kafalarında bir damat çizmişler benim yerime.” K14 (Kadın).

Katılımcıların eş seçiminde önemli olduğunu belirttiği bir diğer unsur ise benzerliktir. Benzerliğin aileler, kültürler, eğitim, hayat görüşü ve inanç gibi alanlarda önemli olduğuna 
dikkat çekilmiştir. Aday eş ile benzer özelliklere sahip olmanın önemini bazı katılımcılar aşağıdaki biçimlerde ifade etmişlerdir.

"Evlilik için iki ailenin benzer kültürden geliyor olması gerekir.” K12 (Kadın).

"Evlenebilmek için hayat görüşlerimiz, aile kavramımız, dini inançlarımızın

benzer olması gerektiğini düşünüyorum.” K3 (Erkek).

Çalışmada bazı kadın katılımcıların eş seçiminde statü ve meslek gibi özelliklere önem verdikleri görülmüştür. Diğer bir deyişle aday eşin statü ve mesleğinin kişinin seçiminde belirleyici olabileceği belirtilmiştir. Bir kadın katılımcı verdiği bu önemi aşağıdaki ifade ile dile getirmiştir.

"Eşimin iş durumunun ya bana denk olması gerekiyor ya da benden daha üst düzey olması gerekiyor.” K7 (Kadın).

Katılımcıların bir kısmı değerlerin eş seçiminde etkin rolüne dikkat çekmişlerdir. Örneğin dini görüş ve politik görüş gibi değerlerin eş seçimlerinde önemli bir unsur olduğunu ifade etmişlerdir. Katılımcılar tarafından oruç tutmak gibi ibadet konusunda benzer yaşantılara sahip olmanın ya da dini görüşün biçimi vurgulamaksızın inanç sahibi olmanın eş seçiminde önemi aşağıdaki biçimlerde dile getirilmiştir.

“Benim için bayramlar önemlidir, Ramazan çok önemlidir. Karşımdakinin de oruç tutmasını ve aynı sofrada iftar olmasını isterim.” K10 (Kadın).

"Evleneceğim kişinin inançsız bir insan olmasını kesinlikle istemem.” K4 (Kadın).

Çalışmada eş seçiminde politik görüşün önemine de dikkat çekilmiştir. Bazı katılımcılar benzer politik görüşe sahip olmanın aradıkları bir özellik olduğunu bildirmişlerdir. Bir katılımcı bu konuya verdiği önemi şu sözlerle dile getirmiştir;

"Benim hayattaki duruşum ve bakış açım göz önünde bulundurulduğunda, evleneceğim kişinin benden çok farklı bir siyasi görüşü olmaması gerekir." K21 (Erkek).

\section{Eş Seçiminde Etkili Olduğu Düşünülen Olumsuz nançlara Dair Görüşler}

Katılımcılara eş seçiminde etkili olduğunu düşündükleri olumsuz inançlar sorulduğunda romantik inançlar, evliliğe dair olumsuz inançlar, toplumsal ve kültürel inançlar, mükemmeliyetçilik, olumsuz örnekleri genelleme (önceki deneyimler ve çevrede gözlemlenenler) temalarının ortaya çıktığı görülmüştür. 
Romantik inançlar teması bireyin eş seçimine ve evliliğe dair eş seçimlerini olumsuz etkilediğini düşündükleri romantik düşünceleri olarak ifade edilmiştir. Katılımcılar romantik inançlar temasında aşık olmalıyım, ilk görüşte etkilenmeliyim gibi inançların ilişkileri başlatma ve sürdürmelerini etkileyebildiğini belirterek eş seçimlerinde olumsuz biçimde etkili olduğunu dile getirmişlerdir. Evliliğe dair olumsuz inançlar teması kişinin evliliğin içerdiğini düşündükleri zorluklara dair kişinin evlilik ve eş seçimine bakışını olumsuz etkileyen düşünceler olarak ifade edilmiştir. Evliliğe dair olumsuz inançlar temasında katılımcılar evlilik kurumuna dair "evlilik zordur”, "evlilik karşılayamayacağım kadar fazla sorumluluk içerebilir" gibi düşüncelerin evlilikten uzaklaşmaları ya da evlilikle ilgili kendilerini yetersiz hissetmelerine neden olduğunu ifade etmişlerdir. Toplumsal ve kültürel inançlar teması katılımcıların eş seçimleri üzerinde olumsuz etkiye sahip olduğunu düşündükleri toplumsal ve kültürel beklentiler olarak belirtilmiştir. Bu temada çocuk sahibi olmalıyım, toplumun evliliğe ve eş seçimine dair beklentilerini karşılamalıyım, ekonomik olarak güçlenmeliyim gibi toplumsal ve kültürel olarak katılımcıları olumsuz etkileyen inançlara değinilmiştir. Ortaya çıkan bir diğer tema olan mükemmeliyetçilik teması, katılımcıların kendisine, aday eşlerine ve ilişkiye dair yüksek beklentileri olarak ifade edilmiştir. Bu temada, katılımcıların eş olarak kendilerine, aday eşlerine ve ilişkiye dair yüksek beklentileri ve kriterlerime uygun olmalı (idealleştirme) gibi düşünceleri ortaya konulmuştur. Olumsuz örnekleri genelleme teması ise kişinin olumsuz deneyim ya da gözlemlerini genellemesi olarak ifade edilmiştir. Bu temada katılımcıların geçmiş yaşantısında yaşadığı ya da çevresinde gözlemlediği olumsuzlukları genelleyerek ilişki ya da evlilikte olumsuzluklar yaşayacakları düşüncesine sahip olabildiği görülmüştür.

Tablo 2. Katılımcıların Eş Seçiminde Etkili Olan Olumsuz nançlara Dair Sık Tekrarlanan Görüşleri

\begin{tabular}{llccc}
\hline Etkili nançlar & & $\begin{array}{c}\text { Kadın } \\
\text { f }\end{array}$ & $\begin{array}{c}\text { Erkek } \\
\text { f }\end{array}$ & $\begin{array}{c}\text { Toplam } \\
\text { fam }\end{array}$ \\
\hline $\begin{array}{l}\text { Olumsuz örnekleri genelleme } \\
\text { (geçmiş yaşantıları ve çevredeki }\end{array}$ & 10 & 6 & 16 \\
örnekleri genelleme, güvensizlik vb.) & olumsuzlukları & & & \\
\hline $\begin{array}{l}\text { Kriterlerime uygun olmalı } \\
\text { (Yüksek beklentiler, idealleştirme) }\end{array}$ & 8 & 4 & 12 \\
\hline $\begin{array}{l}\text { Mükemmeliyetçilik } \\
\text { (kendine, ilişkiye ya da partnere karşı yüksek } \\
\text { beklentiler) }\end{array}$ & 6 & 3 & 9 \\
\hline Evlilik zordur & & & & \\
\hline
\end{tabular}


Tablo 2 incelendiğinde, katılımcıların eş seçiminde etkili olan sık tekrarlanan olumsuz inançları; olumsuz örnekleri genelleme $\left(f_{\text {Toplam }}=16 ; f_{\text {Kadın }}=10 ; f_{\text {Erkek }}=6\right)$, kriterlerime uygun olmalı $\left(f_{\text {Toplam }}=12 ; f_{\text {Kadın }}=8 ; f_{\text {Erkek }}=4\right)$, mükemmeliyetçilik $\left(f_{\text {Toplam }}=9 ; f_{\text {Kadın }}=6 ; f_{\text {Erkek }}=3\right)$ ve evlilik zordur $\left(f_{\text {Toplam }}=6 ; f_{\text {Kadın }}=2 ; f_{\text {Erkek }}=4\right)$ biçiminde siraladıkları görülmektedir. Bunlarla birlikte, aşık olmalıyım $\left(f_{\text {Toplam }}=5 ; f_{\text {Kadın }}=3 ; f_{\text {Erkek }}=2\right)$, evlilik karşılayamayacağım kadar fazla sorumluluk içerebilir $\left(f_{\text {Toplam }}=3 ; f_{\text {Kadın }}=2 ; f_{\text {Erkek }}=1\right)$, ve ekonomik olarak güçlenmeliyim $\left(f_{\text {Toplam }}=1 f_{\text {Kadın }}=0 ; f_{\text {Erkek }}=1\right)$ inançları katılımcılar tarafından eş seçiminde etkili olduğu ifade edilen diğer olumsuz algıladıkları inançlardır. Cinsiyet bakımından ise kadınların çocuk sahibi olmalıyım $\left(f_{\text {Toplam }}=5 ; f_{\text {Kadın }}=4 ; f_{\text {Erkek }}=1\right)$, toplumun beklentilerini karşılamalıyım $\left(f_{\text {Toplam }}=4 ; f_{\text {Kadın }}=4 ; f_{\text {Erkek }}=0\right)$ gibi inançlara erkeklere oranla daha fazla sahip olduğu görülürken, erkeklerin kadınlara oranla daha fazla ilk görüşte etkilenilmeli $\left(f_{\text {Toplam }}=5 ; f_{\text {Kadın }}=1 ; f_{\text {Erkek }}=4\right)$ inancına sahip oldukları görülmüştür.

Katılımcılardan bazıları eş seçiminde etkili olduğunu düşündükleri olumsuz inançlara dikkat çekmişlerdir. Bazı katılımcılar, kendileri tarafından oluşturulan kuralların eş seçim süreçlerinde etkin olduğunu bildirmişlerdir. Bu kurallar ve olumsuz inançlar aşağıdaki biçimlerde örneklenerek ifade edilmiştir.

"Kafamda eş adayına dair bir kurallar listesi var ve ne yapsam bu kuralların dışına çıkamıyorum. Bu sıkı kural ve düşüncelerin beni olumsuz etkilediğini düşünüyorum.” K15 (Erkek).

"Çok fazla kriterim var. Mesela okuduğu üniversiteye kadar bakıyorum. puçlarından tüme varıyorum. Giyim tarzına bakarım, mesleğine bakarım.” K10 (Kadın).

Çalışmada özellikle bazı kadın katılımcılar tarafından toplumsal beklentilerin etkisine dikkat çekilmiştir. Toplumsal beklentileri karşılamaya dair inançların kişilerin eş seçimini etkileyebildiği ifade edilmiştir. Bu toplumsal beklentileri bir kadın katılımcı aşağıdaki biçimde belirtmiştir.

“Akraba ziyaretlerinin hemen hemen hepsinde konu ee yok mu birine zamanı geldiye geliyor. Biraz mahalle baskısı var üzerimde. Bu da beni etkiliyor.” K4 (Kadin).

Çalışmada, katılımcıların eş seçmelerini güçleştiren inançlardan birinin evliliğin zor olduğuna dair düşünceler olduğu görülmüştür. Diğer bir deyişle evliliğin içerebileceği 
güçlüklere dair düşüncelerin eş seçimlerini olumsuz biçimde etkileyebileceği ifade edilmiştir. Bazı katılımcılar bu düşüncelerini aşağıdaki biçimlerde dile getirmiştir.

“Evlenmek çok zor bir süreç düşüncesi eş seçmemi ve evlilik sürecine girmemi oldukça zorlaştırıyor.” K20 (Erkek).

"Bana ilişkiler çok sorumluluk isteyen çok problemli bir şeymiş gibi geliyor. Bu olumsuz düşüncelerim yüzünden denemekten hep korkuyorum.” K23 (Erkek).

"Fedakarlık istiyor evlenmek. Özellikle bir kadın olarak, bir de çalışıyorsan. Evlenince sorumluluklarım iki üç katına çıkacak mesela." K12 (Kadın).

Çalışmada ortaya çıkan bir diğer inanç ise evliliğe dair olumsuz örnekleri genellemenin eş seçimini etkilediğidir. Katılımcılar çevrelerinde gördükleri olumsuz örneklerden yola çıkarak evlilik hakkında olumsuz yargılarda bulunabildiklerini belirtmişlerdir. Bir katılımcı olumsuz örnekleri genellemesini aşağıdaki biçimde ifade etmiştir.

"Çevremdeki evlilikler de beni çok etkiliyor. Hepsinin problemleri var, hepsi dert yanıyor. O beni olumsuz etkiliyor. Zaten genellemeye yatkınım.” K16 (Erkek).

\section{Eş Seçiminde Etkili Olan Dokuz Tip Sınırlayıcı nanca Dair Görüşler}

Katılımcılara Larson (1992) tarafından eş seçiminde etkili olduğu belirtilen sınırlayıcı inançlar teker teker sorulup katılıp katılmadıklarını açıklamaları istendiğinde bazı katılımcıların eş seçimine dair sınırlayıcı inançlara çeşitli biçimlerde katıldıkları görülmüştür (Tablo 3).

Tablo 3. Katılımcıların Eş Seçiminde Etkili Olan Sınırlayıcı nançlara Dair Görüşleri

\begin{tabular}{lccc}
\hline nançlar & Kadın & Erkek & Toplam \\
& f & f & f \\
\hline Birlikte yaşama & 7 & 7 & 14 \\
\hline Mükemmel eş & 5 & 4 & 9 \\
\hline Seçim yapmak kolaydır/şans ve tesadüf & 7 & 2 & 9 \\
\hline Çaba sarf etme & 4 & 4 & 8 \\
\hline Mükemmel ben & 3 & 4 & 7 \\
\hline Mükemmel ilişki & 3 & 3 & 6 \\
\hline Tek ve yalnız & 2 & 2 & 4 \\
\hline Aşk yeterlidir & 2 & 1 & 3 \\
\hline Farklılıklar çeker & - & 2 & 2 \\
\hline
\end{tabular}


Tablo 3 incelendiğinde, özellikle birlikte yaşamanın ileriki evliliğin başarısını artıracağına dair inanç birçok katılımcı tarafından kabul görmüştür $\left(f_{\text {Toplam }}=14 ; f_{\text {Kadın }}=7\right.$; $f_{\text {Erkek }}=7$ ). Katılımcıların yaygın olarak sahip oldukları diğer inançlar sırasıyla mükemmel eş $\left(f_{\text {Toplam }}=9 ; f_{\text {Kadın }}=5 ; f_{\text {Erkek }}=4\right)$, seçim yapmak kolaydır (şans ve tesadüflerden etkilenir) $\left(f_{\text {Toplam }}=9 ; f_{\text {Kadın }}=7 ; f_{\text {Erkek }}=2\right)$, çaba sarf etmek eş seçiminde önemlidir $\left(f_{\text {Toplam }}=8 ; f_{\text {Kadın }}=4\right.$; $\left.f_{\text {Erkek }}=4\right)$, evlenmek için mükemmel ve kendimden emin olmalıyım $\left(f_{\text {Toplam }}=7 ; f_{\text {Kadın }}=3\right.$; $\left.f_{\text {Erkek }}=4\right)$ ve evlenmek için mükemmel ilişkim olmalı $\left(f_{\text {Toplam }}=6 ; f_{\text {Kadın }}=3 ; f_{\text {Erkek }}=3\right)$ inançlarıdır. Katılımcıların en az katıldığı sınırlayıcı inançlar ise evleneceğim kişi benden farklı özelliklere sahip olmalı $\left(f_{\text {Toplam }}=2 ; f_{\text {Kadın }}=0 ; f_{\text {Erkek }}=2\right)$, evlenmek için aşk yeterlidir $\left(f_{\text {Toplam }}=3 ; f_{\text {Kadın }}=2 ; f_{\text {Erkek }}=1\right)$ ve dünyada evlenebileceğim tek ve yalnız bir kişi vardır $\left(f_{\text {Toplam }}=4 ; f_{\text {Kadın }}=2 ; f_{\text {Erkek }}=2\right)$ inançlarıdır. Katılımcılardan bazılarının eş seçiminde sınırlayıcı inançlara dair bazı görüşleri aşağıdaki biçimlerde sunulmuştur.

"Bu işin çok ciddi bir iş olduğunu düşünüyorum. şin ucunda çocuk yapıyorsun ve bir hayat paylaşıyorsun. Evlenilecek kişinin herkes için tek bir doğru kişi olduğunu düşünüyorum.” K12 (Kadın).

"Ben bir kere evlenirim kafasıyla bakıyorum. Daha çok tek ve doğru bir ilişki olduğunu ve bunu bulmaya çalıştığımı düşünüyorum.” K2 (Kadın).

"Karşımdaki mükemmel olursa ben evlenirim. Aradığımı bulana kadar öyle bir işe girmek istemiyorum. Sanırım eş seçiminin duygusal tarafını ihmal ediyorum. Bu beni olumsuz etkiliyor.” K10 (Kadın).

“Eş seçiminin şans ve kaderden etkilendiğini düşünüyorum. Birazcık da işi kader kısmete bırakmak insanı psikolojik olarak rahatlatıyor. Üzerinden bir yük alıyor." K7 (Kadın).

“Tamamen kısmet işi, olmayınca olmuyor. Bunun şans eseri olması mesela benim zoruma gidiyor. Haksızlık gibi geliyor bana. Şuan benim hayatımdaki tek eksik bu mesela. Şansa bağlı olması üzücü bir durum.” K4 (Kadın).

"Birlikte yaşamanın eş seçimi için önemli olduğuna inanıyorum. Öyle tabularım olmasa aslında bana göre bu çok önemli evlilikten önce olması gerekir.” K12 (Kadın).

"Evlenmeden aynı evde yaşamak gerektiğine inanıyorum. Keşke böyle bir toplumda yaşamasaydık da bu kriter zorunlu bir kriter olsaydı. Sürpriz yumurtadan ne çıkarsa gibi geliyor bana birlikte yaşamadan.” K22 (Erkek). 
"Evleneceğim kişi benden farklı biri olsun isterim. Mesela ben ani tepkiler verebiliyorum o daha 1lımlı olsa çok sevinirim.” K18 (Erkek).

\section{Sonuç, Tartışma ve Öneriler}

Çalışmada ilk olarak eş seçimini etkileyen özelliklere dair katılımcıların görüşlerine başvurulmuştur. Bulgular 1şı̆̆ında eş seçimini etkileyen özelliklerin kişisel özellikler, değerler, çevrenin etkisi, çiftler arasındaki uyum, fiziksel çekicilik ve maddiyat gibi özellikler olduğu ortaya konulmuştur. Bu bulgular Tüzemen ve Özdağoğlu'nun (2007) eş seçiminde etkili olduğunu belirttiği kişisel özellikler, çevresel özellikler ve ikili ilişkiler kategorileri ile benzerlik göstermektedir. Çalışmada eş seçiminde önemi vurgulanan olumlu kişilik özellikleri (Buss ve diğ., 1990; Bozgeyikli ve Toprak, 2013; Hatfield ve Sprecher, 1995; Usluoğlu, Atıc1 ve Vurgeç-Avcıbay, 2015), saygı, iletişim becerisi, dürüstlük (güvenilirlik), eğitim düzeyi (Pınar, 2008; Skopek, Schulz ve Blossfeld, 2010; Tüzemen ve Özdağoğlu, 2007), zeka ve sağlık (Buss ve dĭ̆., 1990) gibi özellikler pek çok çalışmanın bulguları ile tutarlılık göstermektedir (Bacanlı, 2001; Buss ve diğ., 1990; Yıldırım, 2007). Özellikle eğitimin önemli bir özellik olarak birçok katılımcı tarafından belirtilmesi çalışmanın katılımcılarının lisansüstü eğitim düzeyinde eğitime önem veren bir grup olması ile açıklanabilir. Bunun yanında evrim kuramına göre iyi eğitim almış olmanın iyi bir ebeveyn adayı olmak ve iyi kaynaklara sahip olmaya aday olmakla açıklanabileceği düşünülmektedir.

Değerler bakımından ise katılımcılar politik ve dini görüş açısından benzer görüşlere sahip olmanın büyük oranda eş seçiminde önemli olduğunu vurgulamışlardır. Bu bulgu eş seçiminde ideoloji ve dini görüş açısından benzerliğin istendik bir özellik olabileceğini belirten bir çok çalışmanın sonuçları ile benzerlik göstermektedir (Buss, 1985; Buss ve diğ., 1990; Bozgeyikli ve Toprak, 2013; Durmazkul, 1991; Usluoğlu ve diğ., 2015; Yıldırım, 2007). Çalışmadaki bazı katılımcılar ailenin onayı, uyumu ve benzerliğinin eş seçimlerinde önemli olduğuna alanyazınla uyumlu biçimde dikkat çekmiştir (Bozgeyikli ve Toprak, 2013; Tüzemen ve Özdağoğlu, 2007; Usluoğlu ve diğg., 2015). Bu bulguyu Türk toplumunun aile yapısı ile açıklamak mümkündür. Türk kültüründe bireyler bağımsız fakat duygusal olarak aileye bağlı davranışlar göstermektedir (Kağıtçıbaşı ve Ataca, 2005). Bu durumun bireyin eş seçim sürecinde de mutlaka etkili olacağı düşünülmektedir. Bunların yanında çalışmada alanyazınla tutarlı biçimde erkeklerin eş seçiminde önemli düzeyde fiziksel çekiciliğe önem verdiği (Geher, 2013), kadınların ise ekonomik güç (Buss ve diğ., 1990) ve sosyal statü (Bacanlı, 2001; Geher, 2013; Valentine ve Li, 2012) gibi özellikleri dikkate aldıkları görülmüştür. Evrimsel bakış açısından bu sonuçlar sürpriz değildir. Günümüzde sosyal 
statünün iyi kaynak sağlamanın bir habercisi olduğu (Geary, Vigil ve Byrd-Craven, 2004), fiziksel çekiciliğin ise üremek için sağlıklı genlerin habercisi olduğunu söylemek mümkündür (Buss, 1994; Buss, Shackelford, Kirkpatrick ve Larsen, 2001).

Çalışmada ikinci olarak ise eş seçiminde etkili olduğu düşünülen olumsuz inançlar araştırılmıştır. Katılımcılarla yapılan görüşmeler sonucunda eş seçiminde etkili olduğu düşünülen en yaygın olumsuz algıladıkları inançların romantik inançlar, evliliğe dair olumsuz inançlar, olumsuz örnekleri genelleme, toplumsal ve kültürel inançlar, ve mükemmeliyetçilik olduğu görülmüştür. Bireylerin genelde yaşadıkları romantik duygulardan hareketle evlilik sürecine girdikleri bilinmektedir. Birçok çalışma romantik inançların yetişkin bireylerde yaygın olduğunu belirtmiştir (Holmes, 2007; Lazarus, 2001; Medora, Larson, Hortaçsu ve Dave, 2002; Sprecher ve Metts, 1999). Ülkemizde ise doktora öğrencileri ile yapılan bir çalışmada eş seçiminde en çok dikkate alınan özelliğin sevgi olduğu bildirilmiştir (Tüzemen ve Özdağoğlu, 2007). Buss ve diğerlerinin (1990) 37 farklı kültürde yürüttüğü çalışmasında, bu çalışmanın bulguları ile tutarlı olarak tüm kültürlerde her iki cinsiyetin de karşılık çekimi ve aşkı eş seçiminde dikkate alınan özellikler olarak sıraladığı bildirilmiştir. Aşk ve sevginin evlilikte önemli bir rolü olabileceği yadsınamayacak bir öneme sahipken, diğer taraftan, romantik inançların ise her zaman işlevsel olmadığına, aşkın iyi bir evliliği garanti edeceği düşüncesinin romantik mitlerden biri olduğuna dikkat çekilmektedir (Ellis ve Bernard, 1985).

Bu çalışmanın bir diğer bulgusu, evliliğe dair olumsuz inançların ve olumsuz örnekleri genellemenin eş seçiminde etkili olabileceğidir. Bu bulgu Pınar'ın (2008) bulguları ile tutarlılık göstermektedir. Üniversite öğrencileri kendileri için evliliğin sorumluluk alma (\%94.2) ve monotonlaşma (\%25.7) gibi olumsuz algılanabilecek kavramlar olduğunu bildirmişlerdir. Beck’e göre (1989) geçmiş yaşantıların ve deneyimlerin bireyin ilişkilerle ilgili düşüncelerini etkileyebilmektedir. Bireyler evliliğe dair bir takım yüksek beklentiler ve mitlerle evliliğe girmekte ve bu gerçekdışı inançlar bireylerin hayal kırıklığg yaşamasına neden olabilmektedir (Larson, 2016). Çalışmalar ilişkiye dair gerçekçi olmayan inançların evlilik doyumunu (Lazarus, 2001) ve ilişki doyumunu (Stackert ve Bursik, 2003) olumsuz etkilediğini bildirmektedir.

Çalışmada elde edilen bulgularda toplumsal ve kültürel inançlar teması altında, çocuk sahibi olmalıyım, toplumun evliliğe ve eş seçimine dair beklentilerini karşılamalıyım, ekonomik olarak güçlenmeliyim gibi inançların önemine dikkat çekilmiştir. Bu bulgu Evrim kuramının eş seçiminde önemini vurguladığı üreme ve kadınların statü ve maddiyata değer verdiğine dair bulgularla örtüşmektedir (Buss, 1989, 1994). Bununla birlikte toplumun 
özellikle evlilik yaşı konusunda kadından bir beklentiye sahip olması kadınlarda üremenin toplumsal önemi (Topdemir Koçyiğit, 2012) ve kadınlarda üreme yaşının belli bir sınırı olması nedeniyle eş seçiminde üremenin dikkate alınan bir özellik olması ile açıklanabilir.

Son olarak katılımcılar mükemmeliyetçiliğin eş seçimlerini önemli biçimde etkilediğini ortaya koymuşlardır. Romantik ilişkilerde idealleştirmenin alanyazında yaygın bir düşünce olduğu (Simpson, Fletcher ve Campbell, 2001) ve idealle gerçeklik arasındaki tutarlılık ne kadar fazla ise ilişki niteliğinin daha yüksek algılandı̆̆ı belirtilmektedir (Fletcher, Simpson ve Thomas, 2000). Mükemmeliyetçiliğin ilişkilere dair boyutunun yakın ilişkilerde etkili bir kavram olduğu (Larson, 1992; Matte ve Lafontanie, 2012) ve bu kavramın romantik ilişkilerde zayıf ilişki işleyişinin yordayıcısı olduğu bildirilmektedir (Haring, Hewitt ve Flett, 2003).

Çalışmanın son kısmında ise, katılımcılara Larson (1992) tarafından belirtilen eş seçiminde sınırlayıcı olarak tanımlanan inançlara katılıp katılmadıklarını belirtip nedenlerini açıklamaları istenmiştir. Katılımcılar çeşitli düzeylerde birçok inanca katıldıklarını belirtirken, en yaygın olan inançların birlikte yaşama, mükemmel eş, seçim yapmak şans ve tesadüflerden etkilenir, çaba sarf etmek eş seçiminde önemlidir, evlenmek için mükemmel ilişkim olmalı, evlenmek için mükemmel ve kendimden emin olmalıyım düşünceleri olduğu görülmüştür. Çalışmalar, birlikte yaşamanın evliliğe bir geçiş süreci gibi değerlendirilebildiğini (Bramlett ve Mosher, 2002) fakat birlikte yaşayanların evli olanlara kıyasla daha düşük ilişki kalitesine sahip olduğunu (Brown ve Booth, 1996) ve birlikte yaşamanın ayrılıkla sonuçlanabildiğini (Bramlett ve Mosher, 2002) göstermektedir. Bununla birlikte, evlenmek için mükemmelliğe (mükemmel eş, ilişki, ben) yapılan vurgunun gerçekdışı inançlara dayandığı belirtilmektedir (Larson, 1992). Mükemmeliyetçiliğin kararsızlıkla (Leong ve Chervinko, 1996) ve zayıf evlilik işleyişi ile ilişkili olduğu bildirilmektedir (Haring ve diğ., 2003). Romantik ilişkilerde

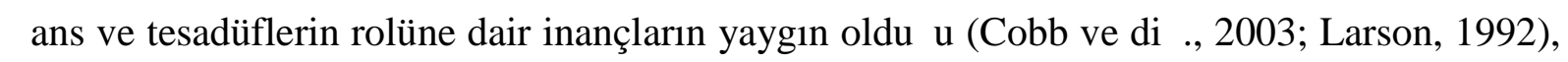
fakat ilişkilerde kader anlayışının ilişki işleyişi bakımından olumsuz sonuçlar doğurabileceğine dikkat çekilmektedir (Knee, Nanayakkara, Vietor, Neighbors ve Patrick, 2001). Bunun yanında kişilerin eş seçiminde çaba sarf etmenin önemine inandıklarını belirten çeşitli çalışmalar bulunmaktadır (Cobb ve diğ., 2003; Larson, 1992; Priest, Burnett, Thompson, Vogel ve Schvaneveldt , 2009). Çalışmanın bulgularında ortaya çıkan inançların kültürümüzde yapılan diğer çalışmalarla benzer olduğu görülmüştür (Cihan Güngör, Yılmaz ve Balcı Çelik, 2011; Yılmaz, Cihan Güngör ve Balcı Çelik, 2013). 
Lisansüstü öğrencilerinin eş seçiminde etkileyen ve sınırlandıran görüş ve inançları belirlemeyi amaçlayan bu çalışma, eş seçiminde etkili olan özellik ve sınırlayıcı inançların anlaşılmasını sağlamak bakımından önem taşımaktadır. Bu çalışmanın bulguları sadece bir üniversitenin lisansüstü öğrencileri ile sınırlıdır. Çalışmanın sonuçlarının daha geniş kitleleri yansıtması için farklı eğitim düzeyinden bireylerle gerçekleştirilmesi önemli olacaktır. $\mathrm{Bu}$ çalışmadan elde edilen bulguların, bireylerin eş seçim sürecinde etkili olan özellik ve gerçekdışı inançlarını ele almak noktasında üniversite ve aile danışma merkezlerine katkı sunacağı düşünülmektedir. Çalışmanın bulguları katılımcıların eş seçiminde işlevsel olmayan birtakım inançlara sahip olduklarını göstermiştir. leriki çalışmalarda, bu inançların değiştirilip yerine eş seçimine dair işlevsel inançların yerleştirilmesini hedefleyen eğitim ve grup programları geliştirilmesi önemlidir. 


\section{Kaynakça}

Bacanlı, H. (2001). Eş tercihleri. Psikolojik Danışma ve Rehberlik Dergisi, 2(15), 7-16.

Baucom, D. H. ve Epstein, N. (1990). Cognitive-behavioral marital therapy. New York: Brunner/Mazel.

Beck, A. T. (1989). Love is never enough. London: Penguin.

Benokraitis, N. V. (2014). Marriages \& Families: Changes, choices, and constraints (8. Bask1.). Boston: Pearson.

Bozgeyikli, H., ve Toprak, A. G. E. (2013). Üniversiteli gençlerin eş seçim kriterlerinin sıralama yargılarıyla ölçeklenmesi. Gençlik Araştırmaları Dergisi, 1(1), 68-87.

Bramlett, M. D. ve Mosher, W. D. (2002). Cohabitation, marriage, divorce, and remarriage in the United States. Vital Health Statistics, 23(22), 1-32.

Brown, S. L. ve Booth, A. (1996). Cohabitation versus marriage: A comparison of relationship quality. Journal of Marriage and the Family, 58(3), 668-678.

Buss, D. M. (1985). Human mate selection: Opposites are sometimes said to attract, but in fact we are likely to marry someone who is similar to us in almost every variable. American Scientist, 73(1), 47-51.

Buss, D. M. (1989). Sex differences in human mate preferences: Evolutionary hypotheses tested in 37 cultures. Behavioral and Brain Sciences, 12(01), 1-14. doi: http://dx.doi.org/10.1017/S0140525X00023992

Buss, D. M. (1994). The strategies of human mating. American Scientist, 82(3), 238-249.

Buss, D. M., Abbott, M., Angleitner, A., Asherian, A., Biaggio, A., BlancoVillasenor, A., ...Yang, K. S. (1990). International preferences in selecting mates a study of 37 cultures. Journal of Cross-Cultural Psychology, 21(1), 5-47. doi: $10.1177 / 0022022190211001$

Buss, D.M., Shackelford, T.K., Kirkpatrick, L.A.,ve Larsen, R. J. (2001). A half century of American mate preferences: The cultural evolution of values. Journal of Marriage and the Family, 63(2), 491-503.

Cihan Güngör, H. , Yılmaz, M. ve Balcı Çelik, S. (2011). Romantizm ve eş seçimi tutum ölçeğinin uyarlanması: Geçerlik ve güvenirlik çalışması. Türk Psikolojik Danışma ve Rehberlik Dergisi, 4(36), 180-190. 
Cobb, N. P., Larson, J. H. ve Watson, W. L. (2003). Development of the attitudes about romance and mate selection scale. Family Relations, 52(3), 222-231.

Creswell, J. W. (2007). Qualitative inquiry and research design: Choosing among five traditions. (2. Bask1.). Thousand Oaks, CA: Sage Publications.

Darwin, C. (2008). On the origin of species. Canada: Sterling Publishing.

Durmazkul, A. (1991). Cinsiyete göre üniversite öğrencilerinin eş seçim tercihleri. (Yayımlanmamıs yüksek lisans tezi). Hacettepe Üniversitesi, Ankara.

Eagly, A. H., ve Wood, W. (1999). The origins of sex differences in human behavior: Evolved dispositions versus social roles. American Psychologist, 54(6), 408-423.

Ellis, A. ve Bernard, M. E. (1985). Clinical applications of Rational-Emotive Therapy. New York: Plenum Press.

Fletcher, G. J. O., Simpson, J. A., ve Thomas, G. (2000). Ideals, perceptions, and evaluations in early relationship development. Journal of Personality and Social Psychology, 79(6), 933-940. http://dx.doi.org/10.1037/0022-3514.79.6.933

Geary, D. C., Vigil, J. ve Byrd-Craven, J. (2004). Evolution of human mate choice. The Journal of Sex Research, 41(1), 27-42.

Geher, G. (2013). Evolutionary psychology 101. New York: Springer Publishing Company.

Haring, M., Hewitt, P. L. ve Flett, G. L. (2003). Perfectionism, coping, and quality of intimate relationships. Journal of Marriage and Family, 65(1), 143-158.

Hatfield, E. ve Sprecher, S. (1995). Men's and women's preferences in marital partners in the United States, Russia, and Japan. Journal of Cross-Cultural Psychology, 26(6), 728750. doi: https://doi.org/10.1177\%2F002202219502600613

Holmes, B. M. (2007). In search of my “one-and-only”: Romance-related media and beliefs in romantic relationship destiny. The Electronic Journal of Communication, 17(3/4), 129.

Johnson, V. I. (2009). The effects of intimate relationship education on relationship optimism and attitudes towards marriage. (Yayımlanmamış doktora tezi). The University of Montana, United States of America. 
Kağıtçıbaşı, Ç. ve Ataca, B. (2005). Value of children and family change: A threedecade portrait from Turkey. Applied Psychology, 54(3), 317-337. doi: 10.1111/j.14640597.2005.00213.x

Kalkan, M. (2012). Eş seçim kuramları. çinde M. Kalkan ve Z. Hamamcı (Ed.), Evlilik öncesi psikolojik danısma. (s. 21-40). Ankara: Anı Yayıncılık.

Knee, C. R., Nanayakkara, A., Vietor, N. A., Neighbors, C. ve Patrick, H. (2001). Implicit theories of relationships: Who cares if romantic partners are less than ideal?. Personality and Social Psychology Bulletin, 27(7), 808-819.

Knox, D. ve Schacht, C. (2008). Choices in relationships: An introduction to marriage and the family. Wadsworth: Cengage Learning.

Larson, J. H. (1992). "You're my one and only": Premarital counseling for unrealistic beliefs about mate selection. American Journal of Family Therapy, 20(3), 242-253. doi: $10.1080 / 01926189208250893$

Larson, J. H. (2016). Myths about marriage. çinde G. R.Weeks, S. T.Fife ve C.M. Peterson (Ed.), Techniques for the couple therapist: Essential interventions from the experts. (s. 194-198). New York: Routledge.

Larson, J. H. ve Holman, T. B. (1994). Premarital predictors of marital quality and stability. Family Relations, 43(2), 228-237. doi: 10.2307/585327

Lazarus, A. A. (2001). Marital myths revisited: A fresh look at two dozen mistaken beliefs about marriage. California: Impact Publishers.

LeCompte, M. D. ve Goetz, J. P. (1982). Problems of reliability and validity in ethnographic research. Review of Educational Research, 52(1), 31-60.

Leong, F. T. ve Chervinko, S. (1996). Construct validity of career indecision: Negative personality traits as predictors of career indecision. Journal of Career Assessment, 4(3), 315-329. doi: https://doi.org/10.1177\%2F106907279600400306

Levinger, G. (1976). A social psychological perspective on marital dissolution. Journal of Social Issues, 32(1), 21-47. doi: 10.1111/j.1540-4560.1976.tb02478.x

Matte, M. ve Lafontaine, M. F. (2012). Assessment of romantic perfectionism: Psychometric properties of the romantic relationship perfectionism scale. Measurement and 
Evaluation in Counseling and Development, 45(2), 113-132. doi: https://doi.org/10.1177\%2F0748175611429303

Maxwell, J. A. (2009). Designing a qualitative study. çinde L. Bickman ve D. J. Rog (Ed.), The Sage handbook of applied social research methods (2.Bask1, s. 214-253). Thousand Oaks, CA: Sage.

Medora, N. P., Larson, J. H., Hortaçsu, N. ve Dave, P. (2002). Perceived attitudes towards romanticism: A cross-cultural study of American, Asian-Indian, and Turkish young adults. Journal of Comparative Family Studies, 33(2), 155-178.

Miller, G. (2000). The mating mind: How sexual choice shaped the evolution of human nature. New York: Anchor.

Priest, J., Burnett, M., Thompson, R., Vogel, A. ve Schvaneveldt, P. L. (2009). Relationship dissolution and romance and mate selection myths. Family Science Review, 14, 48-57.

Pınar, G. (2008). Üniversite son sınıf öğrencilerinin evliliğe bakış açısı. Aile ve Toplum, 10(4), 49-60.

Schellenberg, J. A. ve Bee, L. S. (1960). A re-examination of the theory of complementary needs in mate selection. Marriage and Family Living, 22(3), 227-232.

Sharp, E. A. ve Ganong, L. H. (2000). Raising awareness about marital expectations: Are unrealistic beliefs changed by integrative teaching? Family Relations, 49(1), 71-76. doi: 10.1111/j.1741-3729.2000.00071.x

Skopek, J., Schulz, F. ve Blossfeld, H. P. (2010). Who contacts whom? Educational homophily in online mate selection. European Sociological Review, 27(2), 180-195. doi:10.1093/esr/jcp06

Simpson, J. A., Fletcher, G. J. ve Campbell, L. (2001). The structure and function of ideal standards in close relationships. çinde G. J. O. Fletcher ve M. S. Clark (Ed.), Blackwell handbook of social psychology: Interpersonal processes. (s. 86-106). Oxford: Blackwell Publishing.

Sprecher, S. (1998). Social exchange theories and sexuality. Journal of Sex Research, 35(1), 32-43. doi: 10.1080/00224499809551915 
Sprecher, S. ve Metts, S. (1999). Romantic beliefs: Their influence on relationships and patterns of change over time. Journal of Social and Personal Relationships, 16(6), 834-851. doi: 10.1177/0265407599166009

Stackert, R. A. ve Bursik, K. (2003). Why am I unsatisfied? Adult attachment style, gendered irrational relationship beliefs, and young adult romantic relationship satisfaction. Personality and Individual Differences, 34(8), 1419-1429. doi: https://doi.org/10.1016/S0191-8869(02)00124-1

Topdemir Koçyiğit, O. (2012). nfertilite ve sosyo-kültürel etkileri. nsan Bilim Dergisi, 1(1), 27-38.

Türkiye statistik Kurumu (2016). Haber bülteni: Evlenme ve boşanma istatistikleri 2016. http://www.tuik.gov.tr/PreHaberBultenleri.do?id=21515 adresinden elde edildi.

Tüzemen, A. ve Özdağoğlu, A. (2007). Doktora öğrencilerinin eş seçiminde önem verdikleri kriterlerin analitik hiyerarşi süreci yöntemi ile belirlenmesi. ktisadi ve dari Bilimler Dergisi, 21(1), 215-232.

Usluoğlu, F., Atıcı, M. ve Avcıbay, B. V. (2015). Women's opinions about mate choices: A qualitative study. Journal of Human Sciences, 12(2), 1484-1502. doi: http://dx.doi.org/10.14687/ijhs.v12i2.3359

Valentine, K. A., ve Li, N. P. (2012) Mate Selection. çinde V.S. Ramachandran (Ed.), Encyclopedia of human behavior.(2. Bask1, s. 564-570). London: Elsevier.

Yıldırım, . (2007). Üniversite öğrencilerinin eş seçme kriterleri. Türk Psikolojik Danışma ve Rehberlik Dergisi, 3(27), 15-30.

Yıldırım, A. ve Şimşek, H. (2011). Sosyal bilimlerde nitel araştırma yöntemleri. (8. Bask1.). Ankara: Seçkin Yayınları.

Yılmaz, M., Cihan Güngör, H.. ve Balcı Çelik, S. (2013). Investigation romance and mate selection myths of university students. International Journal of Social Science, 3(2), 416-427.

Wright, H. N. (1992). Premarital counseling handbook. Chicago: Moody Publishers. 


\section{Extended Abstract}

The purpose of this study is to explore the characteristics and constraining beliefs that influence the graduate students' choice of mate. It is known that the mate selection is influenced by the ideas of the individuals as well as the characteristics that the person regarded. The negative beliefs about mate selection are described as problematic in terms of its possible negative effects in mate selection process (Larson, 1992).

A number of studies have been carried out on the characteristics of the mate in Turkey (e.g. Bacanlı, 2001; Yıldırım, 2007) but a limited number of studies have investigated constraining beliefs that are effective in choosing mates. There has not been a study investigating the characteristics and constraining beliefs which are effective in the selection of mates using qualitative research method in Turkish context. Taking all this into account, it is thought that the information obtained from this study is likely to contribute to individuals in the mate selection process and university counseling centers and family counseling centers while helping individuals in mate selection process.

The sample of this study was composed of 24 heterosexual graduate students, not engaged or married, who were studying at a state university. Fourteen of the students were female $(58.3 \%)$ and 10 of them were male $(41.7 \%)$ and their ages ranged from 23 to 32 years.

For data collection in this study, it was benefited from the interview of qualitative data collection methods. To analyze the data, content analysis method was performed. The transcriptions of the interviews were coded by two different coders in order to increase the reliability of the study. In the study, the deductive method was preferred to investigate the characteristics and negative beliefs affecting mate selection. In addition, the inductive method was used to investigate nine constraining beliefs in mate selection reported by Larson (1992).

Regarding the characteristics affecting the selection of mates in the study, it was observed that the characteristics such as personal characteristics, values, environment effect, harmony between couples, physical attractiveness, and materiality were important characteristics. The participating students noted that personal characteristics such as education, communication, personality, openness to learning and development, trustworthiness, respect, helpfulness, empathy, rationality, humor, intelligence, being strength, being clean, being cheerful, socializing, health and appreciation affect their partner choices. In connection with the environment effect, the participants pointed out the importance of family and friends. In terms of harmony between the couples, the participants stated the necessity of 
paying attention on compatibility with the mate, having similar characteristics and being problem-solver/constructive in the relationship. In particular, male participants expressed that physical attractiveness was effective in the selection of mates, while some female participants stressed the importance of high level of status, occupation and earning, or materiality that is equivalent to theirs.

When asked about negative beliefs that were thought to be effective in the mate selection of participants, they pointed out them as romantic beliefs, negative beliefs about marriage, societal and cultural beliefs, perfectionism, and generalizing negative examples (previous experiences and observations in the environment). The negative beliefs that were effective in the mate choice of the participants; potential mate should be in accordance with my criteria, I must fall in love, marriage is difficult, perfectionism, I should have children, attraction at the first side, I should meet expectations of society, marriage may have too much responsibilities, and I should economically develop.

The constraining beliefs reported by Larson (1992) were asked one by one to the participants and when asked to explain whether they agreed with it or not, it was seen that participants agreed with constraining beliefs on the mate selection in various forms. Among these beliefs, cohabitation, chance and coincidence (ease of effort) perfect partner beliefs were mostly accepted by the participants.

The characteristics affecting mate selection of graduate students in this study are revealed as personal characteristics, values, environment effect, harmony between couples, physical attractiveness, and materiality. In this study, positive personality traits (Hatfield \& Sprecher, 1995, Usluoğlu et al., 2015), respect, communication skills, trustworthiness, and health (Buss et al., 1990) are the characteristics indicated as important characteristics in mate selection. At this point, these findings are consistent with the findings of many studies (Bacanlı, 2001, Buss et al., 1990, Yıldırım, 2007). In terms of values, having similar political and religious views in large scale has emphasis which is parallel to the results of some other studies (Buss et al., 1990, Durmazkul, 1991, Usluoğlu et al., 2015). In addition to these, in the study, male participants emphasize the importance of physical attractiveness in the selection of the mate as consistent with extant literature (Geher, 2013) while the economic power (Buss, 1990) and social status (Bacanl1, 2001; Geher, 2013, Valentine \& Li, 2012) are considered as important in mate selection by the female respondents. 
In terms of negative beliefs, as parallel with the findings of this study, studies show that past experiences can affect the individual's perceptions of relationships (e.g. Beck, 1989). Many studies have shown that romantic beliefs are prevalent in adult individuals (Holmes, 2007, Lazarus, 2001, Medora et al., 2002, Sprecher \& Metts, 1999). Also, the findings showed that perfectionism influences mate selection of participants. The idealization in romantic relations is a widespread idea in the literature (Simpson et al., 2001).

Last, the findings of the study revealed that individuals have some constraining beliefs about mate selection that have emerged in other studies conducted in our culture (Cihan Güngör et al., 2011; Y1lmaz et al., 2013). The findings of this study are expected to contribute to university and family counseling centers. In future studies, it is important to develop training and group programs aiming changing these constraining beliefs. 